\title{
Cross Boarder Trafficking of Women and Children in Sex Industry: A Socio-Legal Prospective
}

\author{
Sachin Sharma ${ }^{1}$, Garima Pal ${ }^{2}$ \\ ${ }^{1}$ Assistant Professor NLU, Guwahati, India \\ ${ }^{2}$ Assistant Professor, Symbiosis Law School, Pune, Maharashtra, India
}

\begin{abstract}
Prostitution is one of the world's oldest trades. There have been several debates on its legalization in India because due to its illegal status women who have entered this trade find it hard to report the abuse. In order to find their livelihood large number of women and girls cross border. In their journey they come in contact with agents, who in the name of good 'job' lure them into sex industry. The conditions become graver as there in no proper law to deal with such issues. There are three Acts that govern this trade, Suppression of Immoral Traffic in Women and Girl Act -1956, Prevention of Immoral Traffic Act-1956 and the Immoral Traffic (Prevention) Act1956.The only law governing the area is Immoral Traffic Prevention Act, 1956 (ITPA) which is generally overlooking the core issue. As per our legal scholars and policy makers, trafficking is nothing more than prostitution. Therefore a woman, who has fallen into prostitution, albeit under coercion, ceases to be innocent. Therefore while practicing sex-trade she is no more a 'victim'. According to this narrow thinking, the trafficked women's 'innocence' and 'pure victimhood' has been wrongfully interpreted and she becomes unworthy of assistance. This denies her autonomy and agency, a point sharply criticized under feminist jurisprudence. The main research question here is: Can we treat sex workers as the legal subject so that they can claim their legitimate rights and live a dignified life? Further what policies should be framed for rehabilitation and repatriation of these exploited women and children? By following the doctrinal method author tries to find justification by observing philosophical theories of Robert Nozik, Martha Nussbaum, Immanuel Kant, John Locke, Chhatrapati Singh which says that law on this issue should be of epistemological and ontological in nature. Only then we can stop exploitation of these people and serve the humanity. Now there is need to follow the new paradigm shift on the topic.
\end{abstract}

Keywords: Law, harassment, sexuality, humanity, poverty and sex industry

"Not until a women of exceptional purity and strength of character rises and devoted herself to the task of redeeming this portion of fallen humanity, will the problem of prostitution be tackled. No doubt man can do much among men who degrade themselves by enticing young women to sell themselves for their lust. Prostitution is as old as the world, but I wonder if it was ever a regular feature of town life that it is today. In any case a time must come when humanity will rise against the curse and make prostitution a thing of past as it has got rid of many evil customs, however time honored they might have been."

\section{- Mahatma Gandhi}

\section{Introduction}

In democratic countries like ours, where the slogan is ,government of people, for the people and by the people and where the Constitution is based on a broad concept of „welfare ${ }^{e e}$, which speaks about equality, freedom and dignity. The question remains that, do these precious concepts can really have their access to eachand every person? Who are those people who are unable to found their two time meal? How many days those unfortunate parents are continuously going to give water to their children when they complain about hunger, or somehow when once manage little flour, give half-cooked chappati with pinch of salt, or if conditions further improved serve with onion to their beloved ones? Due to such a severe poverty younger people of family are forced to find any job so that they cannot remain burden on their families. In a process they cross the border and enter into neighboring countries. This way large number of Women and young girls are entering into India. In their journey they come in contact of agents who in the name of good job lure them into sex industry which resulting in severe exploitation of such innocent faces. The situation is so severe that it is impossible for them to come out from this hell and they start living there as their misfortune. The condition becomes more severeas the law starts treating them as an accused rather than victim. Further any other possibility of their rehabilitation in society gets diminished due to the narrow outlook of society who called them as immoral and characterless (though accepting their services in a hidden way). The point is strongly criticized by the feminist like Martha Nussbaum [Martha Nussbaum,Sex and Social Justice 276-299 (Oxford Publications, London, 2001], who treats sex work (based on free will) as a profession and compare it with the professions like lawyer, doctor or teacher.

The area of concern is that:Is law and order working in a direction to achieving that golden stage which leads to the creation of a ,just society ${ }^{\text {ee }}$, where all can live freely in a way they want?Is the law going to help the,AamAadmi"? The system becomes so complex and technical that it is almost impossible for common women/men to exercise their rights as vested by constitution. All policies from agriculture to education and further to employment are being decided by sitting in an air conditioned rooms, where policy makers are ignorant of the practical situation of the matter. For example for any welfare policy of state government, the rule demands from applicantstheir birth certificate, proof of Panchayatarea (in village area), their rashan card and various other attested document. But for a poor, old and illiterate person how it is possible that she/he can easily bring all such documents.Similarly while framing policies on prostitution and trafficking, policy makers treat prostitutes as mere accused neglecting the trauma and agony suffer by them 


\section{International Journal of Science and Research (IJSR) \\ ISSN (Online): 2319-7064}

Index Copernicus Value (2013): 6.14 | Impact Factor (2014): 5.611

through the hands of society and their customers both.In lack of effective law and policy sex trade is so much in practice that owner of many organizations, N.G.O's and rehabilitation centers are running this business behind the curtain.Practically there is no one to help them and they are forced to live a miserable life. Furtherif a prostitute wants to start a new business, can she be accepted by society, and can law provide her shelter, if so how effectively? In the name of equality, dominant class is exploiting the weaker. Hence the basic question is that: how is the exploitation in the name of law, possible? Working of any society necessitates the acceptance of certain rules. These rules are made intuitively by neglecting the individual's conditions. This is the main characteristic of positivist ideology based on axiomatic propositions, unaware of nature of the law.

In order to make law to be just, it must based on society's welfare, otherwise it would deprive people from freedom and make obstacles in their natural growth. There is need to act by following the ontological and epistemological aspects of law, which both lead to a point called "Nyaya" in Chhatrapati Singh [Chhatrapati Singh is the Indian Philosopher who tries to redefine the Law in his work "Anarchy to Utopia"] sense and is the combination of both logic and justice, probably the much needed aspect of law. In order to form just and intelligible law/ proposition, we have to fulfill the conditions of validity, existence and effectiveness. It is only through this we can create coherence in a changing society and which can be done if we have clear ,teleos" [The term is used by Aristotle means purpose] of law.

\section{Relation between Trafficking and Prostitution}

If prostitution is the oldest profession of the world then trafficking is as old as prostitution. It is the mode to facilitate and enhance the sex trade. As the trafficking of women and children for sexual exploitation is a highlyprofitable and low risk game for those who organize it, but it is highly harmful to the millions of women and children exploited even worse than slavery-like conditions in the sex industry. This trade is like an outrage and a worldwide plague, conducted throughout the world with near immunity.

Under the United Nation Convention Against Transnational Organized Crime, 2000- "trafficking in persons" shall mean the recruitment, transportation, harboring or receipt of persons by means of the threat or use of force or other form of coercion, of fraud, of abduction, of deception, of the abuse of power or position of vulnerability or giving or receiving money or benefits to achieve the consent of a person having control over another person, for the purpose of exploitation." [Trafficking protocol, Article 3a] Hence it is clear from this definition that exploitation includes sexual exploitation, forced labor, slavery, servitude etc. However the scope of this paper is limited socio-legal aspect of trafficking of women and children for sexual exploitation. The technical language may have some other meaning but the millions of women and children preyed upon, abused and prostituted in such appalling conditions that trafficking has been identified as a contemporary form of slavery or even worse than it. Therefore while making law and policy on the issue it is very important to consider the strong relation between the two. It is the trafficking which gives the way to all other problem. Hence trafficking and not the prostitution should be our agenda in mind while arguing on the topic. Any mistake in understanding the issue will change the whole matrix and may cause injustice to million innocent people. Probably the prevalent situation is its example.

\section{Conceptual understanding and causes of the problem}

Sex trafficking is more than an issue of crime or migration; it is an issue of the human rights, a manifestation of persistent gender inequality and the subordinate status of women globally. Around the world most trafficked people are women and children of low socio-economic status. The demand aspect of the sex trafficking remain the least visible. When demand is not analyzed or is mentioned rarely, it becomes easy to forget that people are trafficked in to sex industry to satisfy the demand of the customers. The insatiable demand for women and children in massage parlors, strip shows, brothels pornography, escort services and street prostitution is what make the trafficking trade the profitable investment.

Few studies shows that men's reasons for buying sex include a desire for sex without commitment or emotional involvement, the perception that they can ask a prostitute to do anything including the acts they would hesitate to request to their regular partner, the belief particularly among men without regular partner, that sex is necessary to their well being a basic need, and the feeling of power experienced in sexual encounters with prostitutes [Davidson J. (1996). "The sex exploiter." The working document for World Congress against Commercial Sexual Exploitation of Children, Stockholm. www.usemb.se/childern/csec/2166htm]. Women and girls lined up in the brothels are constantly being humiliated. The Coalition Against Trafficking in Women (CATW) has described the expansion of sex trafficking as a reaction against the feminist movement [Ibid.].

The poverty is the one of main cause which limits the choices of the people and gives birth to the trafficking. Again the discrimination against women in education, employment and wages can leave them with very few options for supporting themselves and their families. Even migration through formal channels is not possible for these women. While dreaming of the batter life in another country they become vulnerable to traffickers ${ }^{\text {ee }}$ false promises of good jobs. In addition to exploiting to economic need, traffickers exploit the vulnerability of women and children who have fled their homes because of violence or have been displaced by armed conflict or natural disasters.Further women 's vulnerability to manipulation and exploitation by traffickers is increased by the physiological impact and social stigma of victimization.

In the dynamics of global demand and supply related to sex industry, traffickers practice their entrepreneurial skills. Due to the latent activities of the traffickers there is little information about the trafficker's routes, networks and

\section{Volume 5 Issue 2, February 2016}




\section{International Journal of Science and Research (IJSR) \\ ISSN (Online): 2319-7064}

Index Copernicus Value (2013): 6.14 | Impact Factor (2014): 5.611

associations with organized crime. This is the main cause thatthey can practice their trade with impunity. International and domestic laws are lacking or insufficient; where the laws do exist, there are various loopholes in them. Further corruption contributes heavily to trafficker's real and perceived impunity through the police and immigration

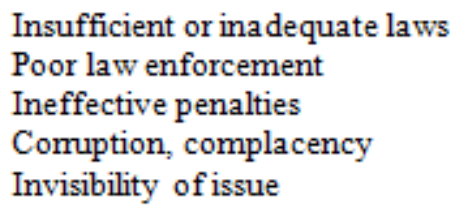

officials who collude, accept bribe, or turn a blind eye. Though the government policies are against the trafficking, but it is missing the core of the issue i.e. protecting the victim and leading to their accusation.

\section{Demand}

Social construction of male sexuality

'Boys will be boys'

Objectification of women's bodies

Perception that prostitutes cannot say no

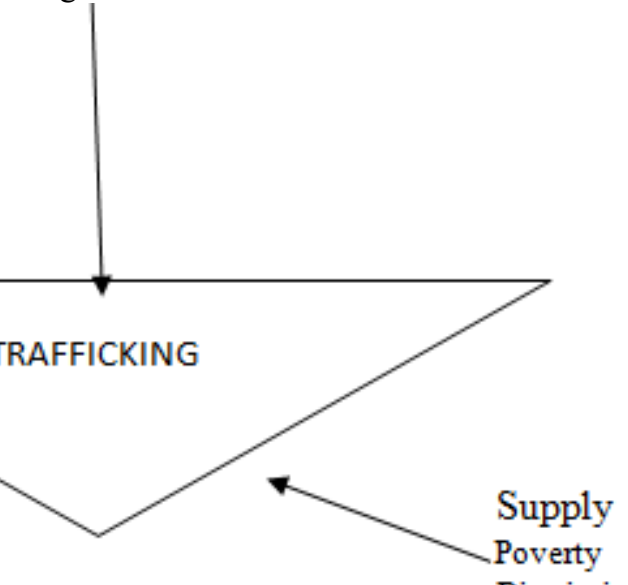

Discrimination unemployment

Gender-based against women

Female violence

Dreams of a better life

Restrictive immigration policies

Lack of information about

Migration risks
It is clear from the above diagram that demand and supply factor play an important role in the trafficking.

\section{Trafficking and society (trafficked person as a victimized individual):}

The crime of trafficking involves the violation of a whole gamut of laws and human rights. It becomes a threat to society because traffickers operate across borders with impunity, with the growing involvement of organized criminals and by generally undermining the rule of law. Trafficking, threatens the very fabric of society ${ }^{\text {ee }}$ because it involves not only criminals but also law enforcers. It manifests and perpetuates patriarchal attitudes and behavior, which undermine the efforts to promote gender equality and eradicate discrimination against women and children. This is illustrated by reports from Albania, which ,document villages where nine in 10 girls over 14 stay away from school because they are afraid of being trafficked ${ }^{\text {ee }}$. Thus, this fear, alters the choices that girls make about their futures ${ }^{\text {ee }}$. Similar instances have been reported in the survey by BNWLA.

A study by Asian Development Bank notes that the ,economic losses to communities and governments are enormous if considered in terms of lost returns on human or social capital investments. The cost of countering criminal trafficking activities puts additional strain on the already limited government resources for law enforcement. A vast amount of potential income from trafficked labour is lost in ,hidden ${ }^{\text {ee }}$ sectors $^{\text {ee }}$. Specific communities may become known as potential sources for people if following each other's example, communities start a trend of sending their children and women out. The loss of future productivity and earning power through low educational levels, ill health and potentially premature death is also felt at the country and regional level. Poor nations can ill afford to lose their young people, whose present and future productive capacity is essential to growth.... The ravage of disease, including HIV/AIDS, is also an enormous burden on such countries and causes further imbalances between the young and middle-aged potential workforce (most likely to be affected) and older people dependent on them (ILO 2002a: 29).

\section{Magnitude of trafficking:}

The scale of the phenomenon is difficult to judge. It is very difficult to collect data on trafficking because of the clandestine nature of the operations. As there is direct relation between the trafficking and prostitution therefore it is important to understand about prostitution. If we see the origin of word „Prostitute phrase prostituta, and it is often cited as a composition of ,pro"means ,up front" or forward and situere, defined as ,to offer up for sale"e. Therefore in order to fulfill that ,offere, there is need to have strong supply side, which is maintained through strong trafficking network.

The ,trade is secretive, the women are silenced, the traffickers are dangerous and not many agencies are countinge (Hughes 2000). Among the most quoted figures are the United Nations estimates that , 4 million people are year are traded against their will to work in some form of slavery, many of them children ${ }^{\text {ee }}$ and believes that, in the last 30 yeas, trafficking in women and children for sexual exploitation in Asia alone has victimized more than 30 million peoplee (Westwood n.d.). A study by Congressional Research Service for the US Congress cities the following estimates of trafficked people worldwide: South-East Asia $\square$ 


\section{International Journal of Science and Research (IJSR) \\ ISSN (Online): 2319-7064 \\ Index Copernicus Value (2013): 6.14 | Impact Factor (2014): 5.611}

225,000; South Asia $\square$ 15,000; former Soviet Union $\square$ 100,000; East Europe $\square$ 75,000; Latin America $\square$ 10,000; Africa $\square 50$ crores (CRS 2001). Recent ILO figures for children in the worst forms of labour worldwide are: trafficking (1.2 million); forced and bonded labour 5.7 million); armed conflict (0.3 million); prostitution and pornography (1.8 million); and illicit activities ( 0.6 million) (ILO 2002) [ADB . 2002. Combating trafficking of women and children in South Asia: Nepal report. Asian Development Bank]

Now looking from the Indian prospective, both prostitution and trafficking for prostitution were prevalent from the ancient time in their various forms. Shamefully in the country of Durga (Goddess of Hindu religion), which is said to be the creator of srishthi(world), women is treated as mere object of entertainment. The discrimination of women from womb to tomb is well known. In ancient India women was used to perform dance in Rajdarbara of kings. There is a great demand for best and beautiful dancers all over, and for that kings used to pay handsomely. Many time this resulted into exploitation (through various ways) of these dancers. Further they had no status in the eyes of society. The ideology of the society was so stereotype that people didn ${ }^{\circ} \mathrm{t}$ recognize them as the part of the society.

The ideology of people is so narrow even today that it was difficult to talk about anything which is criticized by society. In order to overcome this prevalent problem of trafficking in sex industry there is extreme need to have public talk on the issue, as it is only through combine efforts of society we can made a check on exploitation. There is firstly need to understand the core relationship between trafficking and prostitution so that we can take a concrete step to control the atrocities happening on these victimized people.Despite criticizing them there is need to make them the part of the society, so that they can gain the confidence to live a dignified life, which they are lacking. Calculations of trafficked people are generally made with reference to CSE. In India, the stigma attached to prostitution and the clandestine nature of operations make it doubly difficult to arrive at authentic numbers (Gupta 2003). To give a sense of the total magnitude of the problem, estimates of adult and child sex workers in India are quoted. All minors in commercial sex work are generally classified as cases of trafficking. The figures quoted show a high degree of discrepancy, and the possibility of ascertaining the authenticity of the quoted figures is almost nil. The original sources, or how these figures have been arrived at, are rarely stated. Around 30 to 90 per cent of women and girls are under 18 at the time of entry in to prostitution (Mukherjee and Das, 1996; UNICEF 1994: 10; YMCA 1995: 10; Gathia 1999; Gathia 2003: 9, SOS 2001). The population of women and children in sex work in India is stated to be between 70,000 and 1 million. Of these, 30 per cent are 20 years of age. Nearly 15 per cent began sex work when they were below 15, and 25 per cent entered between 15 and 18 years (Mukherjee and Das, 1996). A news item published in Statesman (12 August 2002) states that roughly 2 million children are abused and forced into prostitution every year in India. A rough estimate prepared by an NGO called End Children's Prostitution in Asian Tourism reveals that there are around 2 million prostitutes in India; 20 per cent among them are minors. A study conducted in 1992 estimates that any one time, 20,000 girls are being transported from one part of the country to another (Gupta 2003).According to Latest NCRB records, the stats suggest that there is a drop in figures of trafficking among women and children from 2012 to 2013 ( 108:100) [A report on Trafficking of women and children in India (2002-2003),Sankar Sen,P M Nair].

Table No 1

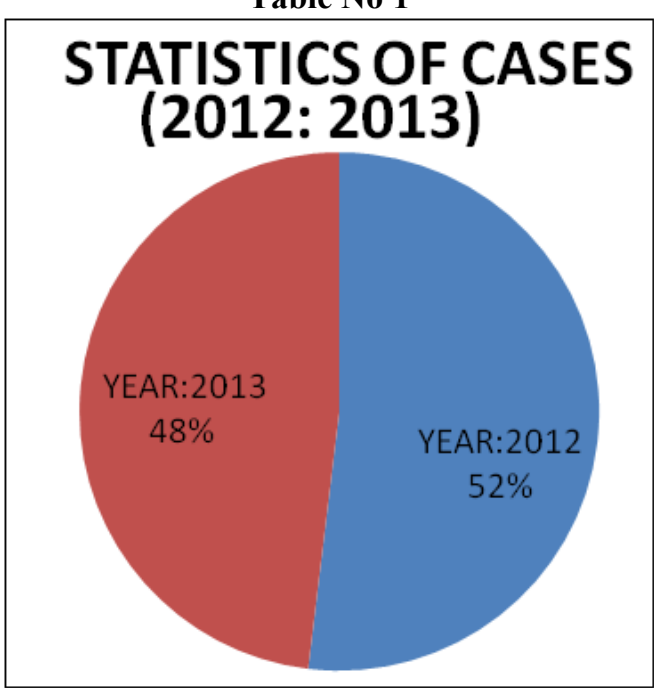

These trafficked women and girl children were sold to various brothel owners or ,Mafias", who in the name of nutrition injected them with Human Growth Harmon(HGH) drugs so that the five- seven year old girls looks like of sixteen- eighteen. There is great demand for the teenage girls in sex market, where ,seth" pays handsomely for what they called their ,enjoyment". Just think for a second that what these innocent and unaware girls would feel while going through the hands of these monsters (of humanity), who ruined them as cotton is ruined while renovating a cotton blanket (Rjaee). How their innocent smile is being converted into bloody tears? To whom they made their complaint? To whom they begged for mercy? The one who are using their lives as a cotton doll for satisfying their humanity less lust! Or to one who had introduced them with such monsters! Or to a police officer who got huge amount of money for allowing all this before his eyes! Or to their parents who unwillingly and compulsively throw her into such an abattoir! Or to that God who write their luck with such a resentment! Or to themselves as that she is a women or girl!How many times in a day we think about this hideous seen, and if one thinks, then what he/she is doing despite showing serious grief. Is there anything which saves her from such a torment called hell and how effectively? What happens to this so called ,welfare State ${ }^{e e}$ when it turn its face towards that poor and deprived family who forces their beloved daughters to find income source? Where does this Constitution goes, to which we call ,Bhagwat Gita "of Law? What Karmas (wrongs) had they committed that she took birth in such a poor and sorrowed family and how legitimate it is to say that it is the punishment of her "Purvajanma" acts?

There is another side of the picture also, there are women who in order to overcome their poverty and finding subsistence for herself and for their children, choose 


\section{International Journal of Science and Research (IJSR) ISSN (Online): 2319-7064 \\ Index Copernicus Value (2013): 6.14 | Impact Factor (2014): 5.611}

prostitution as her profession, which we think, is a quite good as compare to committing robbery, theft and murder like heinous crimes. But if her customer refuses to pay her the agreed amount or injure her, where would she go? Is she is having any protection underlaw? Can she raise her voice before court? The answer will be in negative as she doesn't have any status, further as her act itself is illegal and against "public morality and policies", hence it is void ab initio. Interestingly it is the same society who is taking her services though in a hidden way. But question remains that where she can go for relief? Or just continuously live as she was living before, by tolerating all such brutalities and crimes, which itself is equal to committing a crime. If we provide legal status to these exploited women, it can help them for improving their conditions and status.

\section{Justification of Law for a Just society}

In order to create a just society, law has to be just i.e. it shouldbe based on reason; otherwise it would deprive people from freedom and create obstacles in their natural growth. But by following the positivist model of law, we are strangling the poor person. There is need to act by observing the ontological and epistemological aspects of law, which lead to a point called "Nyaya" in Chhatrapati Singh [Hereinafter "CS"] sense and is the combination of both logic and justice, probably the much needed aspect of law. Therefore, there is need to add both ideas and actions and this result in formation of a world where all can live with a reasoned manner [Reference is made to Kingdom of Ends by Immanuel Kant]. But we are only following the idealistic model and neglecting the realistic one. Perhaps it is the main cause of our problems. Hence there is need to apply a legal theory which tries to evaluate the valid legal rules having their moral ,end ${ }^{\text {ee }}$ and ,mean ${ }^{\text {ee }}$. For this there is need to keep law above from all religious and political elements. By following above said model we can bring justice and equality in society and protect that last needed person from grave injustice. For making any proposition complete there is need to make a proposition with having proper combination of its object, subject and nexus. For example if we are going to make legal proposition for Prostitutes then we have to make „Prostitutes ${ }^{\text {ee }}$ as a legal subject, „Their rights and welfare ee as object, ,Law which makes them the part of society as Nexus. Another important requirement is the non contradiction between basic legal proposition and other propositions, for example like constitution and laws which denies the legal status to prostitutes.

It is the moral principles of state to form a basic legal proposition, possibly by giving due importance to the conditions of people to which they belong. Therefore all norms which are made by observing the ground realities [This includes all religious, political, economical, educational, recreational conditions prevalent in society] are termed as intelligible and effective. But truth is that while making such norms we only concerned about ,what ${ }^{\text {ee }}$ and ,how ${ }^{\text {ee }}$ questions while ignoring the ,why ce completely, the most important in finding those ground realities. This can be achieved by applying those nine Heuristic principles [Chhatrapati Singh, Law from Anarchy to Utopia42-43 (Oxford Publication, Delhi, 1987)], as they cover all requirements for proper system. Once we succeed in making such proposition, it become effective forever, even while exercised by different administrative hands. This way theory gives importance to the morality that law promotes among men. It is the duty of the law to provide conditions for free communication between human beings, which help them to act freely in a reasoned manner [Ibid, at 8.]. This helps us in changing our stereotype outlook and provides choice to individual. In order to make a proper law there is need to understand the spirit of law which itself based on the values attached to it, for example equality, fraternity, freedom are the values attached to our constitution. Therefore it is very important to understand and interpret these values of that proposition.

\section{Existing Laws and Trafficking}

\section{(a) International Laws}

The 1949, convention for the suppression of the Trafficking in Persons and the exploitation of the Prostitution of others criminalizes the sex trafficking and acts associated with prostitution, but with week enforcement mechanisms and the adoption by the only 69 countries, it has not been effective. [ Persaud, N., "Sexually transmitted infections, drug use, and risky sex among female sex workers in Guyana", 76(4) Sexually Transmitted Infections 318 (2000)] Convention also failed to address forms of exploitation that were not wide spread in 1949, including mail-order bride industries, sex tourism and trafficking of organs etc. article 6 of UN Convention of elimination of all forms of Discrimination against Women(CEDAW) 1949 [UN Convention of elimination of all forms of Discrimination against Women (CEDAW), 1949 Available at: http://www.un.org/womenwatch/cedaw22/mmr.pdf

(Accessed on 25 July, 2012)] requires state parties to take action to suppress. "All forms of trafficking in women and exploitation of prostitution of women," and CEDAW"s general Recommendation No. 19 specifically mentions the newer forms of exploitation neglected in the 1949 convention. The UN Convention against Transnational Organized Crime, 2000 [UN Convention against Transnational OrganizedCrime, 2000, Available at: http://www.uncjin.org./documents/convention/pdf

(Accessed on 25 July, 2012)] provides a tool for international cooperation against trafficking in its Protocol to Prevent, suppress and punish trafficking in persons, Especially Women and Children. The protocol specifies criminalization, stronger border controls, and increased security and control of documents as preventive mechanisms. It focuses on international cooperation to combat trafficking and details aspects of assistance and protection for victims. In May 2001 the protocol had been signed by 85 countries; thirty-five additional signatures are needed for the protocol to become an instrument of international law. [Ibid] The UN Global Program Against Trafficking in Women, Health and Development Program Trafficking for Sexual Exploitation Human Beings is conducting several technical cooperation projects based on implementation of the protocol. The Inter-American Convention on the prevention, punishment, and eradication of violence against women-Convention of Belem do Para, 1994 [Convention of Belem do Para, 1994, Available 


\section{International Journal of Science and Research (IJSR) \\ ISSN (Online): 2319-7064 \\ Index Copernicus Value (2013): 6.14 | Impact Factor (2014): 5.611}

at:http://cidh.org.basicos/englisb/basic13.cov\%20of\%20Bele $\mathrm{m} \% 20$ Do\%20Para.htm (Accessed on 27 July, 2012)] explicitly names trafficking in persons and forced prostitution as forms of violence against women. As such, States Parties to the convention are called upon to condemn trafficking and pursue policies to prevent, punish and eradicate it.

International instruments specifically addressing the trafficking of children include the ILO Convention 182 Concerning the Prohibition and Immediate Action for the Elimination of the Worst Forms of Child Labor (1999), and the UN Convention on the Rights of the Child (1989) and its Optional Protocol on the Sale of Children [UN Convention on the Rights of the Child, 1989 and its Optional Protocol on the Sale of Children, Available at: http://www.crin.org./treaties/resources(Accessed on 25 July, 2012)], Child Prostitution and Child Pornography (2000) [Child Prostitution and Child Pornography, 2000 Available at: $\quad$ http://www2.ohchr.org/english/law/crc-sale.htm (Accessed on 25 July, 2012)]. Some countries have targeted the exploitation ofchildren in sex tourism, adopting laws that allow for the prosecution of sex crimes against children committedin another country, regardless of that countryes laws. Laws of this type are designed not only to punish thecommercial sexual exploitation of children overseas, but also to deter sex tourists who become situational childabusers due to a perception that the sexual exploitation of children is acceptable in some other cultures.

A handful of countries in the region have laws that specifically prohibit trafficking. Most have a variety of laws under which traffickers could be punished, including facilitating entry or exit from the country for prostitution and sundry laws against pimping [David A. Feingold, "Think Again: Human Trafficking" 150 Foreign Policy 2005]. Considering the evidence of growth in trafficking, it appears that existing laws and/or their enforcement are inadequate. Advocates of legal reform have emphasized a three-ways approach of prevention of trafficking, prosecution of traffickers and protection for victims [U.S State Department "The Protection Project"s Commercial Sexual Exploitation of Women and Children: A Human Right Report 2001"; U.S State Department2001 Report on Trafficking in person]. Further the US Trafficking Victims Protection Act of 2000 outlines minimum standards for the elimination of trafficking: the prohibition of trafficking; punishment of trafficking Acts commensurate with that of other grave crimes, such as forcible sexual assault; punishment stringent enough to provide a deterrent; and "serious and sustained efforts" by governments to eradicate trafficking.

Legal protection of victims is very importance, without it their legal status can become more venerable. Where prostitution is prohibited, victims can be viewed and treated as criminals, rather than crime victims. Victims of international trafficking frequently are illegal aliens and face the dilemma that if they escape to seek help, they may be arrested and deported. Therefore there must be opportunities for victims to seek redress and restitution without risk of further human rights violations. (b) Domestic Laws: The same negative approach of law is continues at domestic level also. As due to the narrow mind set of society, prostitution is, beyond doubt, is social evil. It is supposed as an obnoxious feature of every society. The presumption isbased on the belief that in a theoretically good society, where sexual fulfillment ought to be possible as other kind of personal satisfaction, no one be the prostitute or a client. It is further said that it is the threat to the marriage-family institution. Law-makers are afraid that the delicate threads which bind society together will be broken if people are free to engage in the sexual activity for pleasure. It is stated that laws are not enforced adequately because police has many things to do. Judges are also of the belief that jails are not going to rehabilitate a prostitute. Nevertheless, laws exist to emphasize that prostitution is not a socially acceptable form of behavior. Due to this stereotype behavior of the society, our laws and policy on the issue is also biased with the presumption that prostitution per se is wrong and anyone who is engaged in prostitution by what so ever reason is an accused in spite of victim.

\section{Constitutional Provision and Misuse of the Immoral Trafficking Prevention Act}

Article 23(1) of the constitution prohibits traffic in human beings and provides that any contravention with the provision is an offence and punishable under law. Art. 35(a) also provides that the Parliament shall, as soon after the commencement of the constitution, makes laws for prescribing punishment for the acts which are declared as offence under Part III of the Constitution. Further Article 39(f) provide that State shall direct its policy towards securing that childhood and youth are protected against the exploitation and against moral and material neglect.

As we know that commercial sex work per se is not illegal in India. But according to the Immoral Trafficking Prevention Act, 1956, the main statue dealing with the sex work in India, commercial sex and soliciting in a public place are punishable offence. The Act is intended to protect women from being trafficked, i.e. forced or coerced in selling sex. As stated above that sex work is not itself socially sanctioned but considered immoral, sin or crime. So law enforcement agencies like police misinterpret the ITPA and go after the sex workers instead of the traffickers. Thus sex worker suffer harassment both at the hands of traffickers and the police. As mentioned above the present Act is based on the International Convention for Suppression of Trafficking in Persons and the Exploitation of the Prostitution of others, 1949. On the basis of the convention to which India is a signatory ITPA is based on the principle that sex work is exploitation and is incompatible with the dignity and the worth of the human beings. [The Immoral Trafficking Prevention Act, 1956] The stated goal of the act is to eliminate trafficking; it does not criminalize sex work or sex workers, but rather act by the third parties facilitating the sex work. Thus Act punishes anyone maintaining a brothel, living off earning of prostitution and procuring, inducing or detaining for the sake of prostitution. It also provides for the detention in a, ,corrective institutions ${ }^{e c}$ of a female offender who solicits publicly, suggesting that censure of sex work is inherent in its approach. Therefore most anti-trafficking interventions- including rescue and 


\section{International Journal of Science and Research (IJSR) \\ ISSN (Online): 2319-7064 \\ Index Copernicus Value (2013): 6.14 | Impact Factor (2014): 5.611}

rehabilitation operations- end up either criminalizing or victimizing the sex worker, while having a minimal impact on the traffickers or those responsible for exploitation, who circumvent the law. Data on the enforcement of the Act indicate that over $90 \%$ of those arrested under the Act are women sex workers. The other includes the brothel keepers, pimps and clients [Natraj S."Women in Prostitution in India: some realities", South India AIDS Action Program, Chennai 2001]. Section 7 and 8 of the Act directly target sex workers by penalizing sex work in public place and solicitation, respectively. Section $8 \mathrm{~B}$, under which $90 \%$ of women are arrested, forbids "soliciting in a public place". [Ibid] Usually conviction under these sections is immediate, as sex workers confess to the charge to expedite the proceedings, a better option than being detained. In practice the police use these provisions without actually invoking them, along with the local regulations to harass sex workers, particularly those working in streets. Thus a law aimed at protecting women is being used to punish them [Centre for Feminist Legal Research" Memorandum on Reform of Laws Relating to Prostitution in India", Centre for Feminist Legal Research, New Dehli, 1999]

Loopholes of the Act: The one of the main confusion is regarding the ambit of term 'public place', as Act prohibits the prostitution in the public place or in the vicinity of public place. But there are number of examples where through private areas situated in a public area like shop, house etc. such activities are carried out. Even though there are the provisions for search of places under the Act, but generally it is only sex workers who are detained from such places and the real actors are remains out of reach of police. Further the question arises that is brothel or Red Light Area will come under the ambit of public as they are situated in public place? [The question is raised by considering the general meaning of term ,Public Place" means an area where every person can have his/her access] If we give such a wide scope to term than practically it should be impossible to find a place doing sex trade, but interestingly we have completely reverse situation.

The argument is cleared the following diagram:

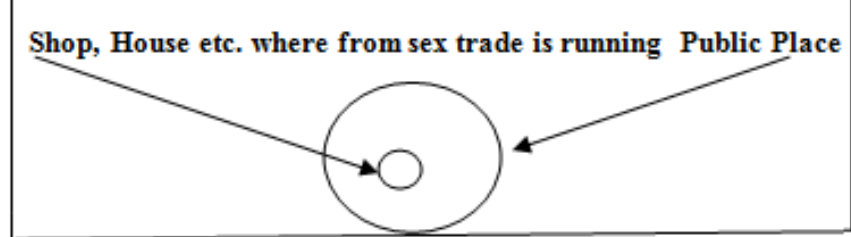

Further sec. 4(1) of the ITPA provides punishment for living on the earning of prostitution. It states that 'any person' over the age of eighteen years who knowingly lives, wholly or in part, on the earning of the prostitution of ,any other person shall be punishable with imprisonment....The wide ambit of the term, any person ${ }^{\text {ee }}$ is troublesome as it can include any individual including the family members of the prostitutes. Perhaps this may be one of the cause that family members of sex workers generally ignore them and hesitate in fighting for their rights, this way only light of hope for sex workers in fighting for their rights is also get diminish. This resulted in the brutal exploitation of sex workers through the hands of traffickers and Dalals.
Again section 10-A of the Act which provide for the detention in a corrective institution where female offender is found guilty under section 7 , in order to make such detention the 'character' of the offender should of such nature that it is expedient that she should be subject to detention. So here section giving the authority to detain a prostitute on the basis of her character, which is very easy to prove as loose. In such a situation she has nothing in her defense, further here is no one going to ask that why she is engaged in such activity in a public area. Even if she is following the instruction of her madam or master, which she has to follow otherwise she has to face a cruelty from them.

\section{Fact sheet on trafficking and prostitution}

In cross border trafficking, India is a sending, receiving and transit nation. Receiving children from Bangladesh and Nepal and sending women and children to Middle Eastern nations is a daily occurrence [Ibid at 24].

- Hundreds, of Bangnadeshi women and children are held in foreign prisons, jails, shelters and detention centers awaiting repatriation. Many have been held for year. In India itself number of women and children are held in various shelters waiting for repatriation. It is an estimate that more than 160,000 Nepalese women are held in India's brothels, and near about 50,000 or more Nepali women are in prostitution in Bombay. [Roboert I. Freidman, "Indiaes shame: Sexual Slavery and Political Corruption Are Leading to An AIDS Catasrophe," 24-27 The Nation 1996]

The brothels of India hold between 100,000 and 160,000 Nepalese women and girls, 35\% were taken on the false pretext of marriage or a good job. [ ${ }^{1}$ RadhikaCoomaraswamy, "UN Special Report on Violence on violence against Women", Gustavo Capdevia, IPS ]

- About 5000-7000 Nepalese girls are trafficked to India every day.

- $70 \%$ of students surveyed at a wealthy high school seek a career in organized crime, citing their reasoning as "good money and good fun". [Ibid. at 27]

- Trafficking in women and girls is easy along 1,740 milelong open border between India and Nepal. 200,000 to over 250,000 Nepali women are already in Indian Brothels. Many of these women are locked up for several days, starved, beaten and burned with cigarettes until they learn how to service up to 25 clients a day. some girls go through training before being initiated into prostitution, which can include constant exposure to pornographic films to please their customers [Soma Wadhwa, "For sale childhood," Outlook, 1998].

- There are 300,000-500,000 children in India [Rahul Bedi, "Bid to Protect Children As Sex Tourism Spreads," London's Daily Telegraph, 23 Aug. 1997].

- Every day, about 200 girls and women enter into prostitution in India and $80 \%$ of them are against their will [Center for Development and Population Activities (CEDPA) and Planning Rural-Urban Integrated Development through Education (PRIDE) ].

- In Bombay, 95\% of children of prostituted women become prostitutes. one child, who had repeatedly been sodomized by the men who brought his mother, dedicated to become a eunuch. He was ritually castrated [Ibid. at 27] 


\section{International Journal of Science and Research (IJSR) \\ ISSN (Online): 2319-7064 \\ Index Copernicus Value (2013): 6.14 | Impact Factor (2014): 5.611}

- The Red light district in Bombay generates at least $\$ 400$ million a year in revenue, with 10,00 prostitutes servicing men 365 days a year, averaging 6 customers a day, at $\$ 2$ each $[I d]$.

Hence it is clear from the above that present Act is not competent enough to effectively deal with the problems, as there are many chances of misusing and misinterpreting of the Act.

\section{Conclusion}

\section{Need to adopt a new Paradigm Shift}

The women and children who have been trafficked and thereafter subjected to commercial sexual exploitation are living embodiments of the social tolerance of the ultimate violation of human rights. These survivors are the largely helpless protagonists of a grim tale of trade in human misery, indulged in by organized exploiters [A report on Trafficking of women and children in India, Sankar Sen ,P M Nair].

In order to frame an effective law and policy the law has to change with the pace of the changing society. Failing in this would result in formation of a week proposition, which hamper the cause of justice in its true sense. There is extreme need to understand the ,teleos "[Ibid., at 3] of law and policy so that we can understand the nature of that particular law and can implement it in a right direction. As mentioned above there are many cases where Act has created various problems for the sex workers as they are harassed in the name of law. Further there is need to understand the relation between law and morality in its wide aspect. While making legislation on the issue like prostitution we starts with the pre-settled mind that the prostitution per se is wrong and immoral. This forces us to made arguments by overlooking the prevalent situation on the issue. While declaring it as an immoral Act we snatch the victimhood status of these women and replace it with that of accused which resulted into their miserable life. There are ample of research which shows that the majority of women engaged in sex industry are forced due to their poverty. The harassment by the law is addition to their exploitation by Dalals. In this long race of trafficking we are catching the looser and the real players are still moving freely in a manner they want. Because whole of our energy is wasted in tracing the prostitutes and the traffickers, who act as agents are free from the grip of the law.

Considering the morality part reference is again given to Martha Nussbaum and Robert Nozick who very rightly indicating the stereo type thinking of the society by arguing that what is wrong in sex work if done with a free will [Ibid., at 1]. It is nothing more than the stereotype attitude of our mind that one way by availing the services of sex works we are recognizing them. This is the only reason that this ,old profession ${ }^{\text {ee }}$ is still surviving and developing. The simple applicable market principle is that any commodity will have its importance in market till that time it has its demand in consumers. Now if we consider the Locke ${ }^{\text {ee }}$ s theory of labor who said that every man is owner of himself in a sense that labor of his body and work of his hands are his property. When he mixes his labor in common state of nature and acquires something it becomes his private property. He gave us a very natural example that when man gather the apples or pick up acorns under an oak tree, it becomes his property. Therefore when a prostitute offer her, ,sex ${ }^{e e}$ as ,sex as work ${ }^{\text {ee }}$, and does so with her agency and choice and charge fee from her customer then it is not equivalent to the selling of fruits for money or giving wage for labor? By treating sex as work is helpful in taking institution of prostitution in nuance directions so that the prostitutes will not be exploited through the hands of traffickers. These are the burning argument of the new paradigm which is keen to treat sex as a work.And perhaps this is the right time when we have to rethink on the issue and decide for the cause of justice. Failure to this will resulted in famous quotation that Justice delayed, Justice denied and this will be the most immoral, unethical and unlawful to the humanity. After being trafficked, women and children are subjected to the most abominable abuse $\square$ physical, verbal, sexual and emotional. The gross violation of their rights is further exacerbated when the victims are arrested as accused, prosecuted and even convicted. Worse, revictimisation ensues through the very process meant to redress their grievances. This shocking state of affairs calls for stern action, via effective use of the available legal provisions, against traffickers, clients and all other abusers; as well as proper arrangements for the adequate care and protection of the survivors, ensuring that their rights are not violated any further. There is an urgent need to provide them with suitable skills, information and resources so that they are economically and socially empowered. Redressal mechanisms should not stop with rescue. They should be expanded to include rehabilitation and reintegration and other measures to ensure that the harm suffered by the victim is not repeated.

Further if we regulate sex work through law in a proper manner than we can stop the exploitation of the sex workers in the hands of the traffickers who are just playing with their senses and emotions. This gives the courage to sex workers to come out and get settled themselves with the social stream by taking the benefits of various social welfare schemes. [Loan given by NABARD to two prostitutes who wants to starts a small scale agricultural industry is one of appreciable example] In order to change the prevalent situation there is extreme need to provide agency to the sex workers so that they can exercise their rights in a manner they want. It is well established fact that prostitution is as old as the society itself.But it is strange to know that in this profession the main performer has no agency on their activities. If we provide sex workers with license etc. facilities it gives them the right to exercise their agency as than they can come out in protest in violation of their rights [There are large number of cases where customer or brothel owners refused to pay money to sex workers and physically and mentally exploit them]. This will result into reduction in cross boarder trafficking of women and children for sex industry.

The role of the government is a prime factor in this whole exercise. As from policy formation to its implementation it is the government in its different form is interacting with the issue. There is only need to win the hearts and gain the faith of sex workers and rest of the problem will going to solve by its own. This can be done by formulating such effective and interactive policies of rehabilitation and development of the 


\section{International Journal of Science and Research (IJSR) \\ ISSN (Online): 2319-7064}

Index Copernicus Value (2013): 6.14 | Impact Factor (2014): 5.611

sex workers. Further as there is large number of women and children of neighboring boarder areas who crossed boarder and under coercion, misrepresentation and wrongful influence of agents forced to join sex industries. Hence it is the obligation of the government to help them in their rehabilitation and repatriation. Regional consultation on implementation of SAARC Convention on Trafficking, 2006 [Community Action Centre Nepal (CAC-Nepal), Final Report submitted to Center for Social Research (CSR) New Delhi, July 2006] is important step in this regard. There is only need to have strong political willingness above from all biasness so that we can implement the convention. This requires the Kantian principle of respect which said human beings are capable of reasoning and therefore should be respected. It is our duty to create a best possible world where all can live in harmony and peace while respecting each other"s rights and needs. This situation can be reached by forming a "Compossible World" [Ibid., at 10] which makes the possibility to live altogether.

\section{References}

\section{List of Books}

[1] Chhatrapati Singh,Law from Anarchy to Utopia (Oxford Publication, Delhi, 1987).

[2] Martha Nussbaum,Sex and Social Justice (Oxford Publication, Delhi, 2000).

[3] K. Lakshmi Raghuramaiah,Night Birds, (Indian Prostitution from Devdasi to Call Girls)(Chanakya Publication, Delhi, 2001).

[4] Miranda Fricker and Jennifer Hornsby, The Cambridge Companion to Feminism in Philosophy (Cambridge Publication, United Kingdom, 1998)

[5] Prof. Fernando Henriques, Prostitution and Society (Mac Gibbon \&Kee Publication, London 1962).

[6] Julia O'Connell Davidson,Prostitution, Power and Freedom (Policy Press, UK, 1998).

[7] Louis Brown,The Dancing Girls of Lahore (Harper Collin Publication, New York, 2005).

\section{List of Reports}

[8] ADB. 2002. Combating trafficking of women and children in South Asia: Nepal report. Asian Development Bank

[9] A report on Trafficking of women and children in India (2002-2003),Sankar Sen,P M Nair.

\section{List of Articles}

[10] Persaud, N., "Sexually transmitted infections, drug use, and risky sex among female sex workers in Guyana", 76(4) Sexually Transmitted Infections 2000.

[11] K. Jayasree"Searching for Justice for Body and Self in a Coercive Environment: Sex Work in Kerala, India"Vol. 12 (23) Sexuality, Rights and Justice2004.

[12] Jo Goodey,"Sex trafficking in women from Central and East European Countries: promoting a ,victim centered ${ }^{\text {ee }}$ and ,women centered approach to criminal justice intervention" 76Feminist Review 2004.

[13] David A. Feingold,"Think Again: Human Trafficking” 150Foreign Policy 2005.

[14] UNIFEM,Trafficking in Women and ChildrenGender Fact Sheet No. 2 (2004).
[15] Donna M. Hughes, Laura Joy Sporcic, et al., "Coalition against Trafficking in Women, Facebook on Global Sexual Exploitation" Online Web: www.uri.edu./artsi./wms/hughes/facebook.html.

\section{List of Websites}

[16] http://www.un.org/womenwatch.

[17] http://www.uncjin.org.

[18] http://www.cidh.org.

[19] http://www.wikipidia.org.

[20] http://www.crin.org. 